\title{
The Coupled Analysis of Electromagnetic Wave and Heat Conduction with Rotational Motion of Heated Target and Temperature-Dependent Complex Permittivity
}

\author{
Yoshifumi Okamoto Member (The Institute of Physical and Chemical Research, okamotoy@riken.jp) \\ Ryutaro Himeno Non-member (The Institute of Physical and Chemical Research, himeno@ riken.jp) \\ Kiminori Ushida Non-member (The Institute of Physical and Chemical Research, kushida@riken.jp) \\ Akira Ahagon Member (Science Solutions International Laboratory, Inc., ahagona@ssil.co.jp) \\ Koji Fujiwara Member (Doshisha University, koji.fujiwara@mail.doshisha.ac.jp)
}

Keywords: finite element method, electromagnetic wave analysis, heat conduction analysis, coupled analysis, rotational motion, temperature-dependent complex permittivity

In order to evaluate the heated process of the target, $S$ parameter, and initial design of cavity size in the dielectric heating furnaces for recycling the plastic wastes including the polyvinyl chloride (PVC), the coupled analysis method of electromagnetic wave and heat conduction (EM-HC coupled analysis) is a useful tool for practical design. In this paper, valuable EM-HC coupled analysis method with rotational motion of heated target such as turntable and temperaturedependnet complex permittivity by using edge-based finite element method is proposed.

The convergence characteristic of incomplete Cholesky conjugate gradient method (ICCOCG method) in electromagnetic wave analysis is poor process by using electric field $\boldsymbol{E}$ and the comoplex ratio $a$ of reflected wave amplitude as unknown variables $(\boldsymbol{E}-\boldsymbol{a}$ formulation). Authors transform the $\boldsymbol{E}$ - $a$ formulation into the magnetic vector potential $\boldsymbol{A}$ and electric scalar potential $\phi(\boldsymbol{A}-\phi-a$ formulation) in order to prevent the poor numerical convergence of ICCOCG method. The convergence characteristics of ICCOCG method is shown in Fig. 1. The iteration number of $\boldsymbol{A}-\phi$ - $a$ formulation is about a quarter number of $\boldsymbol{E}$ - $a$ formulation. The CPU time for solving algebraic equation is reduced to three quarters of $\boldsymbol{E}-a$ formulation by using $\boldsymbol{A}$ - $\phi$ - $\boldsymbol{a}$ formulation as shown in Table 1.

The application of EM-HC coupled analysis is performed in

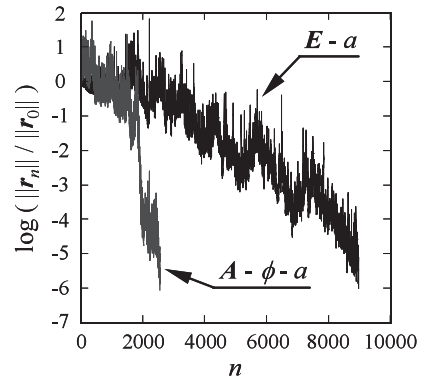

Fig. 1. Convergence characteristics of ICCOCG method

Table 1. Computation time of ICCOCG method

\begin{tabular}{c|c|c|c}
\hline formulation & D. O. F. & iteration number & CPU time \\
\hline $\boldsymbol{E}-a$ & $99,922(1.00)$ & $8,971(1.00)$ & $628.01(1.00)$ \\
\hline $\boldsymbol{A}-\phi-a$ & $132,358(1.32)$ & $2,543(0.28)$ & $459.57(0.73)$ \\
\hline
\end{tabular}

CPU: Intel Pentium $43.72 \mathrm{GHz} / 3.0 \mathrm{~GB}$, COMPILER: Intel Visual Fortran Ver. 9
SHARP made microwave oven. Heated region of PVC sample is widely diffused with turntable motion because the mode of electric filed heavily depends on the rotational position. Therefore, the reflection coefficient $\left|S_{11}\right|$ in input port is changed at each time as shown in Fig. 2. The comparison of temperature rise in high temperature spot against the different time step size is shown in Fig. 3. The relative error of final temperature against the case $\Delta t=0.0666 \mathrm{~s}$ is less than $0.2 \%$ on the condition that the time step size $\Delta t$ is less than $0.3333 \mathrm{~s}$.

As a result of above investigation, the proposed EM-HC coupled analysis method is effective for designing the dielectric heating furnaces for not only the decomposition of waste plastics but also various foods. The proposal of EM-HC coupled analysis method with the rotational motion of stirrer fan and the comparison with experimental results are future works.

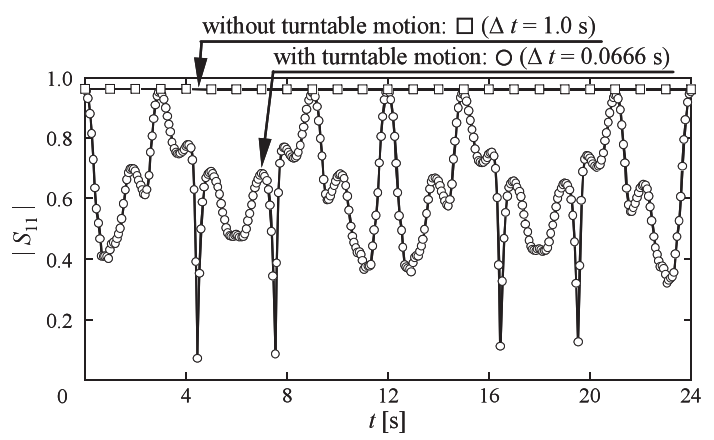

Fig. 2. Time variation of reflection coefficient $\left|S_{11}\right|$

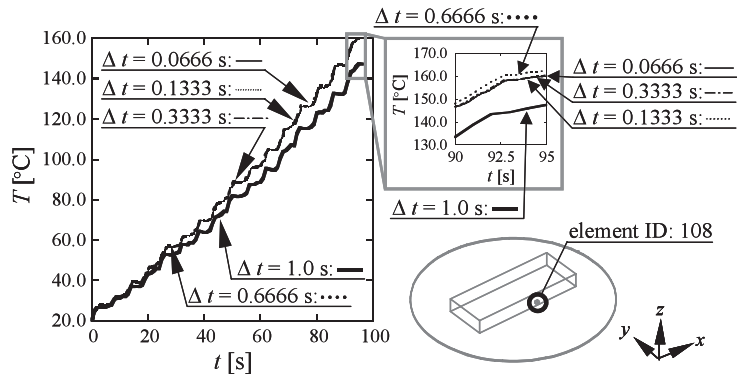

Fig. 3. Effect of time step size on temprature rise 


\title{
被加熱体の回転運動と温度依存性の複素誘電率を考慮した 電磁波・熱伝導連成解析
}

\author{
正 員 岡本 吉史* 非会員 姫野龍太郎* \\ 非会員 丑田 公規** 正 員 阿波根 明*** \\ 正 員 藤原 耕二****
}

\section{The Coupled Analysis of Electromagnetic Wave and Heat Conduction with Rotational Motion of Heated Target and Temperature-Dependent Complex Permittivity}

Yoshifumi Okamoto*, Member, Ryutaro Himeno*, Non-member, Kiminori Ushida**, Non-member,

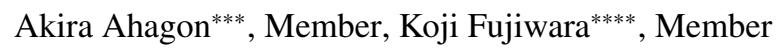

\begin{abstract}
In order to evaluate the heated process of the target, $S$ parameter, and initial design of cavity size in the furnaces for dielectric heating such as microwave oven, the coupled analysis of electromagnetic wave and heat conduction (EM-HC coupled analysis) is a useful tool for practical design. In this paper, valuable EM-HC coupled analysis method with rotational motion of heated target such as turntable and temperature-dependent complex permittivity by using edgebased finite element method is proposed. As a result of useful investigation of the proposed method, the effectiveness in tracing the detailed temperature rise of dielectric target is demonstrated.
\end{abstract}

キーワード : 有限要素法, 電磁波解析, 熱伝導解析, 連成解析, 回転運動, 温度依存性複素誘電率

Keywords: finite element method, electromagnetic wave analysis, heat conduction analysis, coupled analysis, rotational motion, temperature-dependent complex permittivity

\section{1. はじめに}

電子レンジのような誘電加熱機器において, 被加熱体の 発熱状況, 散乱行列, キャビティ寸法などの初期設計值を 数值的に評価するために, 電磁波・熱伝導連成解析は実機 設計の観点から, 重要な手段となる。本論文では, 廃プラ スチック内の塩化ビニル樹脂 (PVC) を誘電加熱によって,

\section{* (独) 理化学研究所 情報基盤センター}

于 351-0198 和光市広沢 2-1

Advanced Center for Computing and Communication, The Institute of Physical and Chemical Research

2-1, Hirosawa, Wako 351-0198

** (独) 理化学研究所 環境ソフトマテリアル研究ユニット

干 351-0198 和光市広沢 2-1

Eco-Soft Material Research Unit, The Institute of Physical and Chemical Research

2-1, Hirosawa, Wako 351-0198

***サイエンスソリューションズ (株)

₹ 153-0065 東京都目黒区中町 2 丁目 21-7

Science Solutions International Laboratory, Inc.

2-21-7, Naka-cho, Meguro-ku, Tokyo 153-0065

**** 同志社大学 工学部電気工学科

T 610-0321 京田辺市多々羅都谷 1-3

Department of Electrical Engineering, Doshisha University

1-3, Tatara-Miyakodani, Kyotanabe 610-0321
効率的に処理するための高効率リサイクル誘電加熱炉の実 機設計を目的とした電磁波・熱伝導連成解析手法の高度化 について検討する。

従来, 電子レンジのような共振器の電磁波・熱伝導連成 解析では, FDTD 法 ${ }^{(1)}$ を用いた解析例が多数報告されてい る (2) (4)。電磁波の伝搬と熱伝導の時間スケールは大幅に異 なるため, FDTD 法のような時間領域の解法と, 非定常熱 伝導解析との連成解析では, 時間スケールの小さい電磁波 解析に追従させる必要があるため, 時間ステップ数が膨大 となる。さらに, 共振器内の電磁界は, 単一周波数で励振 されていることと, 過渡状態よりも共振状態である定常現 象の把握が重要となるため, 周波数領域の解析が効率的で あると考えられる。また, 商用電子レンジ内に取り付けら れているターンテーブルやステラファンのように, 庫内の 特定部分が回転運動するような問題では, 離散化形状が格 子状であると, 回転部と静止部の境界上で格子不整合が生 じるため，解析が困難となる。

そのため, 本研究では, 離散化形状の自由度が高く, 周 波数領域の解析が可能である有限要素法を使用する。その 先行研究として, 文献 (5)では, 三次元場において, 有限 要素法を用いた先駆的な電磁波・熱伝導連成解析手法が提 案されている。しかし, 温度依存性の複素誘電率の取り扱 
い方や熱伝導解析の時間刻み幅が計算精度に与える影響に ついて述べられていない。また, 被加熱体の一様加熱化を 目的として, 商用電子レンジに備え付けられているターン テーブルやステラファン等の回転物体を厳密に模擬した電 磁波・熱伝導連成解析の報告例はほとんどない。

そこで, 本論文では, 有限要素法を用いた温度依存性複素 誘電率, 被加熱体の回転運動を考慮することができる電磁 波・熱伝導連成解析手法を提案する。まず，電磁波解析にお ける計算速度向上を目的として, 複素対称方程式の解法とし て使用する不完全コレスキー分解付き共役勾配法 (ICCOCG 法）の収束特性を改善するため，野村氏らによる電界 $\boldsymbol{E}$ を 未知変数とし, 散乱行列を考慮した弱定式化 ${ }^{(6)}$ を磁気べク トルポテンシャル $\boldsymbol{A}$ と電気スカラポテンシャル $\phi$ を未知変 数とした $\boldsymbol{A}-\boldsymbol{\phi}$ 法 ${ }^{(7)(8)}$ へ拡張した。また, 熱伝導解析の時間 刻み幅が, 回転運動を伴った被加熱体の温度上昇, 計算時 間へ与える影響について検討し，提案手法の有用性を示す ことができたので報告する。

\section{2. 電磁波・熱伝導連成手法}

$\langle 2 \cdot 1\rangle$ 電磁波解析 本節では, 電子レンジのように, マグネトロンと共振器内部を接続する導波管断面において, 共振器側からの電磁界の散乱が容易に扱えるように, 不連 続境界面 (導波管断面) の反射波複素振幅比を未知変数に追 加した $\boldsymbol{E}$ 法に基づく弱定式化 ${ }^{(6)}$ を磁気ベクトルポテンシャ ル $\boldsymbol{A}$ と電気スカラポテンシャル $\boldsymbol{\phi}$ を未知变数とする $\boldsymbol{A}-\boldsymbol{\phi}$ 法へ拡張する。また, 熱伝導方程式とのカップリングを勘 案すると, 電磁波と熱伝導の時間発展スケールは大幅に異 なるので, 電磁界方程式の時間微分項 $(\partial / \partial t)$ を複素数近 似 $(\mathrm{j} \omega)$ した定常解析を採用する。A- $\phi$ 法 (7)(8) を使用した 周波数領域の電磁界方程式を(1)，(2) 式に示す。

$$
\begin{aligned}
& \operatorname{rot}(v \operatorname{rot} \boldsymbol{A})=-\mathrm{j} \omega \varepsilon(\mathrm{j} \omega \boldsymbol{A}+\operatorname{grad} \phi) \\
& \operatorname{div}\{-\mathrm{j} \omega \varepsilon(\mathrm{j} \omega \boldsymbol{A}+\operatorname{grad} \phi)\}=0 \ldots \ldots
\end{aligned}
$$

ここで， $\varepsilon$ は誘電率， $v$ は磁気抵抗率，j は虚数単位， $\omega$ は 角周波数である。なお，本解析では，強制電流，導電性材 料を使用しないため，それらに関係する項を省略している。 次に, 辺要素, 節点要素の補間関数 $N_{i}, N_{j}$ を用いて, (1), (2) 式の弱形式を導出すると，(3)，(4) 式のようになる。

$$
\begin{aligned}
G_{i}^{\text {edge }}= & \iiint_{V} \operatorname{rot} \boldsymbol{N}_{i} \cdot v \operatorname{rot} \boldsymbol{A} \mathrm{d} V \\
& +\iiint_{V} \boldsymbol{N}_{i} \cdot \mathrm{j} \omega \varepsilon(\mathrm{j} \omega \boldsymbol{A}+\operatorname{grad} \phi) \mathrm{d} V \\
& -\iint_{S} \boldsymbol{N}_{i} \cdot(\boldsymbol{H} \times \boldsymbol{n}) \mathrm{d} S=0 \ldots \ldots \ldots \ldots \\
G_{j}^{\text {node }}= & \iiint_{V} \operatorname{grad} N_{j} \cdot \varepsilon(\mathrm{j} \omega \boldsymbol{A}+\operatorname{grad} \phi) \mathrm{d} V \\
& -\frac{1}{\mathrm{j} \omega} \iint_{S} \operatorname{grad} N_{j} \cdot(\boldsymbol{H} \times \boldsymbol{n}) \mathrm{d} S=0 \cdots
\end{aligned}
$$

ここで， $\boldsymbol{n}$ は境界面における外向き法線方向単位ベクトル， $\boldsymbol{H}$ は磁界である。また, 係数マトリクスを対称にするため,

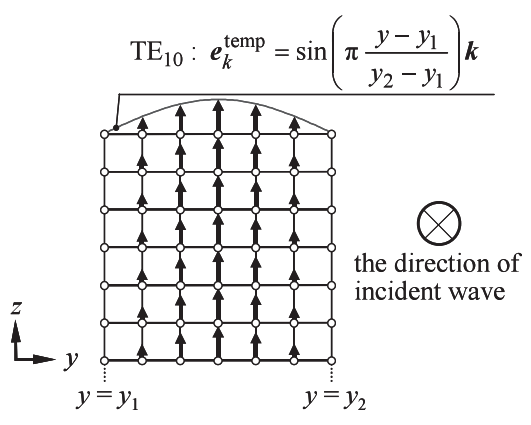

図 1 固有モード関数 $\boldsymbol{e}_{k}$ の計算法

Fig. 1. Computation method of eigen mode function $\boldsymbol{e}_{k}$.

(4) 式の両辺を時間積分している。なお，(4) 式右辺第二項 の境界積分項の導出については，付録を参照されたい。

導波路を解析する場合, 入出力ポートにおける電磁界モー ドは，使用する導波管によって，既知の場合が多い。その ため, ポート $k$ における電界, 磁界の固有モード関数 $\boldsymbol{e}_{k}$, $\boldsymbol{h}_{k}$ をあらかじめ計算しておけば解析が容易となる。ここで は, $\mathrm{TE}_{10}$ モードで励振される固有モード関数 $\boldsymbol{e}_{k}$ の計算方法 について述べる。まず, 図 1 のような正方形格子で分割さ れた方形導波管の入出力ポートを想定し，ポート上の節点 における仮の固有モード関数 $\boldsymbol{e}_{k}^{\text {temp }}$ を(5) 式より計算する。

$$
\boldsymbol{e}_{k}^{\mathrm{temp}}=\sin \left(\pi \frac{y-y_{1}}{y_{2}-y_{1}}\right) \boldsymbol{k}
$$

ここで, $\boldsymbol{k}$ は $z$ 方向単位ベクトル $, y_{1}, y_{2}$ は方形導波管の 境界座標值とする。次に, 伝送電力が $\chi$ となるように, 入 出力ポートにおける $\boldsymbol{e}_{k}^{\text {temp }}$ の規格化を行う。ポート $k$ で使 用されている導波管の特性界インピーダンスを $Z_{k}^{H}$ とする と, $\boldsymbol{e}_{k}, \boldsymbol{h}_{k}$ の関係式は (6) 式のようになる。なお, $Z_{k}^{H}$ は, 導波管の遮断波長および自由空間波長から計算できる ${ }^{(9)}$ 。

$$
\boldsymbol{e}_{k}=Z_{k}^{H}\left(\boldsymbol{h}_{k} \times \boldsymbol{n}\right)
$$

(6) 式を利用すると，ポート $k$ における伝送電力 $\chi$ は，(7) 式のように表すことができる。

$$
\frac{1}{2} \iint_{S_{k}}\left(\boldsymbol{e}_{k} \times \boldsymbol{h}_{k}^{*}\right) \cdot \boldsymbol{n} \mathrm{d} S=\frac{1}{2 Z_{k}^{H}} \iint_{S_{k}}\left|\boldsymbol{e}_{k}\right|^{2} \mathrm{~d} S \equiv \chi
$$

上付き添え字* は共役複素, $S_{k}$ は導波管の入出力ポート面 を示す。次に，(8) 式のように規格化定数 $\alpha_{k}$ を定義する。

$$
\boldsymbol{e}_{k}=\alpha_{k} \boldsymbol{e}_{k}^{\text {temp }}
$$

(8) 式を (7) 式に代入することで, 規格化定数 $\alpha_{k}$ は (9) 式 のように計算できる。

$$
\alpha_{k}=\sqrt{\frac{2 Z_{k}^{H} \chi}{\iint_{S_{k}}\left|e_{k}^{\mathrm{temp}}\right|^{2} \mathrm{~d} S}}
$$

以上より，(5), (9) 式を (8) 式へ代入すると, 伝送電力が $\chi$ となる固有モード関数 $\boldsymbol{e}_{k}$ の計算が可能となる。 


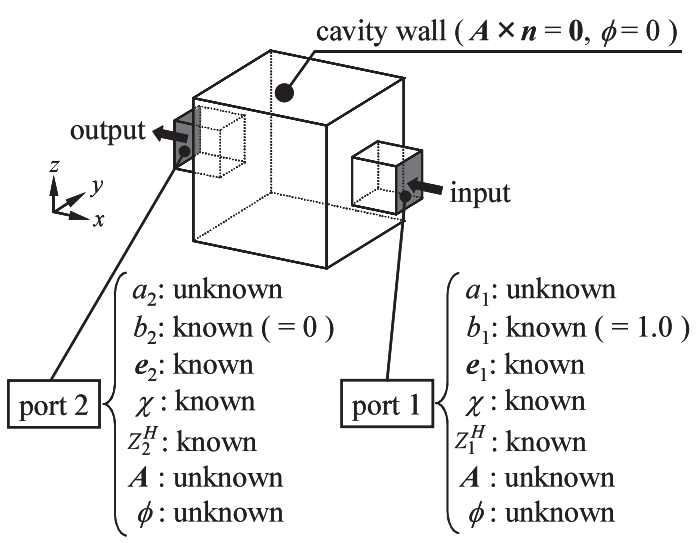

図 2 入出力ポートにおける既知変数と未知变数

Fig. 2. Known and unknown variables on input and output ports.

導波路の解析では，散乱行列の計算を容易にするため，入 出力ポート $k$ における反射波複素振幅比 $a_{k} \quad\left(0<\left|a_{k}\right|<1\right)$ を未知変数に追加することが好ましい。入射波複素振幅比 を $b_{k}$ とし，TEモードで励振された場合を想定すると（TM モードについては，文献(6) を参照)，ポート $k$ における電 界 $\boldsymbol{E}$, 磁界 $\boldsymbol{H}$ は (10), (11) 式のようになる。

$$
\begin{aligned}
& \boldsymbol{E}=\left(a_{k}+b_{k}\right) \boldsymbol{e}_{k} \\
& \boldsymbol{H}=\left(a_{k}-b_{k}\right) \boldsymbol{h}_{k}
\end{aligned}
$$

なお，図 2 に示すように， $a_{k}$ は未知， $b_{k}$ は既知（ポート $k$ が入力ポート $: b_{k}=1.0$, 出力ポート $\left.: b_{k}=0\right)$ である。ま た，(3)，(4) 式における境界積分項は，(6)，(10)，(11) 式 を用いることで，(12)，(13) 式のようになる。

$$
\begin{aligned}
& \iint_{S_{k}} \boldsymbol{N}_{i} \cdot(\boldsymbol{H} \times \boldsymbol{n}) \mathrm{d} S \\
& \quad=\left(a_{k}-b_{k}\right) \iint_{S_{k}} \boldsymbol{N}_{i} \cdot\left(\boldsymbol{h}_{k} \times \boldsymbol{n}\right) \mathrm{d} S \\
& \quad=\frac{a_{k}-b_{k}}{Z_{k}^{H}} \iint_{S_{k}} \boldsymbol{N}_{i} \cdot \boldsymbol{e}_{k} \mathrm{~d} S \ldots \ldots \ldots \ldots \cdot \ldots \\
& \iint_{S_{k}} \operatorname{grad} N_{i} \cdot(\boldsymbol{H} \times \boldsymbol{n}) \mathrm{d} S \\
& =\left(a_{k}-b_{k}\right) \iint_{S_{k}} \operatorname{grad} N_{i} \cdot\left(\boldsymbol{h}_{k} \times \boldsymbol{n}\right) \mathrm{d} S \\
& =\frac{a_{k}-b_{k}}{Z_{k}^{H}} \iint_{S_{k}} \operatorname{grad} N_{i} \cdot \boldsymbol{e}_{k} \mathrm{~d} S \cdots \cdots \cdots
\end{aligned}
$$

3 種類の未知変数 $(\boldsymbol{A}, \phi, a)$ に対して，(3)，(4) 式だけで は方程式の個数が不足しているため，ポインティングベク トルを利用した (14) 式を追加する。

$$
\begin{aligned}
\frac{1}{2 Z_{k}^{H}} \iint_{S_{k}} \boldsymbol{E} \cdot \boldsymbol{e}_{k}^{*} \mathrm{~d} S & =\frac{\left(a_{k}+b_{k}\right)}{2 Z_{k}^{H}} \iint_{S_{k}} \boldsymbol{e}_{k} \cdot \boldsymbol{e}_{k}^{*} \mathrm{~d} S \\
& =\chi\left(a_{k}+b_{k}\right) \ldots \ldots \ldots \ldots
\end{aligned}
$$

以上より，3 種類の解くべき方程式を整理すると，(15) (17) 式のようになる。

$$
\begin{aligned}
G_{i}^{\text {edge }}= & \iiint_{V} \operatorname{rot} \boldsymbol{N}_{i} \cdot v \operatorname{rot} \boldsymbol{A} \mathrm{d} V \\
& +\iiint_{V} \boldsymbol{N}_{i} \cdot \mathrm{j} \omega \varepsilon(\mathrm{j} \omega \boldsymbol{A}+\operatorname{grad} \phi) \mathrm{d} V \\
& -\sum_{k} \frac{a_{k}-b_{k}}{Z_{k}^{H}} \iint_{S_{k}} \boldsymbol{N}_{i} \cdot \boldsymbol{e}_{k} \mathrm{~d} S=0 \cdots \cdots \\
G_{j}^{\text {node }}= & \iiint_{V} \operatorname{grad} N_{j} \cdot \varepsilon(\mathrm{j} \omega \boldsymbol{A}+\operatorname{grad} \phi) \mathrm{d} V \\
& -\sum_{k} \frac{a_{k}-b_{k}}{\mathrm{j} \omega Z_{k}^{H}} \iint_{S_{k}} \operatorname{grad} N_{j} \cdot \boldsymbol{e}_{k} \mathrm{~d} S=0 \\
G_{k}^{\text {scat }}= & -\frac{1}{Z_{k}^{H}} \iint_{S_{k}}\left(\boldsymbol{A}+\frac{1}{\mathrm{j} \omega} \operatorname{grad} \phi\right) \cdot \boldsymbol{e}_{k}^{*} \mathrm{~d} S \\
& -\frac{2 \chi\left(a_{k}+b_{k}\right)}{\mathrm{j} \omega}=0 \ldots \ldots \ldots \ldots . \cdots
\end{aligned}
$$

上記した $\boldsymbol{A}-\boldsymbol{\phi}$ 法に反射波複素振幅比 $a$ を未知変数に追加し た定式化を，以下，A- $\phi-a$ 法と略称する。(15) (17) 式か ら，係数マトリクスを作成すると，(18)式のようになり，左 辺係数行列の $i$ 行 $j$ 列成分を (19) (27) 式に示す。

$$
\begin{aligned}
& {\left[\begin{array}{lll}
\boldsymbol{S}_{\boldsymbol{A}}^{\text {edge }} & \boldsymbol{S}_{\phi}^{\text {edge }} & \boldsymbol{S}_{a}^{\text {edge }} \\
\boldsymbol{S}_{\boldsymbol{A}}^{\text {node }} & \boldsymbol{S}_{\phi}^{\text {node }} & \boldsymbol{S}_{a}^{\text {node }} \\
\boldsymbol{S}_{\boldsymbol{A}}^{\text {scat }} & \boldsymbol{S}_{\phi}^{\text {scat }} & \boldsymbol{S}_{a}^{\text {scat }}
\end{array}\right]\left\{\begin{array}{c}
\boldsymbol{A} \\
\phi \\
a
\end{array}\right\}=\left\{\begin{array}{l}
\boldsymbol{Y}^{\text {edge }} \\
\boldsymbol{Y}^{\text {node }} \\
\boldsymbol{Y}^{\text {scat }}
\end{array}\right\}} \\
& \left.\boldsymbol{S}_{\boldsymbol{A}}^{\text {edge }}\right|_{i, j}=\iiint_{V}\left(v \operatorname{rot} \boldsymbol{N}_{i} \cdot \operatorname{rot} \boldsymbol{N}_{j}-\omega^{2} \varepsilon \boldsymbol{N}_{i} \cdot \boldsymbol{N}_{j}\right) \mathrm{d} V \\
& \left.S_{\phi}^{\text {edge }}\right|_{i, j}=\iiint_{V} \mathrm{j} \omega \varepsilon N_{i} \cdot \operatorname{grad} N_{j} \mathrm{~d} V \\
& \left.\boldsymbol{S}_{a}^{\mathrm{edge}}\right|_{i, j}=-\sum_{k} \frac{1}{Z_{k}^{H}} \iint_{S_{k}} \boldsymbol{N}_{i} \cdot \boldsymbol{e}_{k} d S \\
& \left.S_{A}^{\text {node }}\right|_{i, j}=\iiint_{V} \mathrm{j} \omega \varepsilon \operatorname{grad} N_{i} \cdot N_{j} \mathrm{~d} V \\
& \left.S_{\phi}^{\text {node }}\right|_{i, j}=\iiint_{V} \varepsilon \operatorname{grad} N_{i} \cdot \operatorname{grad} N_{j} \mathrm{~d} V \\
& \left.\boldsymbol{S}_{a}^{\text {node }}\right|_{i, j}=-\sum_{k} \frac{1}{\mathrm{j} \omega Z_{k}^{H}} \iint_{S_{k}} \operatorname{grad} N_{i} \cdot \boldsymbol{e}_{k} \mathrm{~d} S \cdots \\
& \left.\boldsymbol{S}_{\boldsymbol{A}}^{\mathrm{scat}}\right|_{i, j}=-\sum_{k} \frac{1}{Z_{k}^{H}} \iint_{S_{k}} \boldsymbol{N}_{j} \cdot \boldsymbol{e}_{k}^{*} d S \\
& \left.S_{\phi}^{\mathrm{scat}}\right|_{i, j}=-\sum_{k} \frac{1}{\mathrm{j} \omega Z_{k}^{H}} \iint_{S_{k}} \operatorname{grad} N_{j} \cdot \boldsymbol{e}_{k}^{*} d S \\
& \left.S_{a}^{\mathrm{scat}}\right|_{i, j}=-\frac{2 \chi}{\mathrm{j} \omega}
\end{aligned}
$$

なお，(21) 式と (25) 式，(24) 式と (26) 式をそれぞれ比較す ると, $\boldsymbol{e}_{k}$ と $\boldsymbol{e}_{k}^{*}$ が異なっている。しかし, 電界の固有モード 関数 $\boldsymbol{e}_{k}$ を実数のみで評価すれば $\boldsymbol{e}_{k}=\boldsymbol{e}_{k}^{*}$ となり, 係数行列 は対称となるため, ICCOCG 法が適用可能となる。また, キャビティ表面上では，電界の接線方向成分が 0 となるの で, 境界条件として, $\boldsymbol{A} \times \boldsymbol{n}=\mathbf{0}, \phi=0$ を課す。それゆえ, (18) 式の右辺項は, (28)～(30) 式のようになる。

$$
\left.\boldsymbol{Y}^{\text {edge }}\right|_{i}=-\sum_{k} \frac{b_{k}}{Z_{k}^{H}} \iint_{S_{k}} N_{i} \cdot \boldsymbol{e}_{k} \mathrm{~d} S .
$$




$$
\begin{aligned}
\left.\boldsymbol{Y}^{\text {node }}\right|_{i} & =-\sum_{k} \frac{b_{k}}{\mathrm{j} \omega Z_{k}^{H}} \iint_{S_{k}} \operatorname{grad} N_{i} \cdot \boldsymbol{e}_{k} \mathrm{~d} S \ldots \ldots \\
\left.\boldsymbol{Y}^{\text {scat }}\right|_{i} & =\frac{2 b_{k}}{\mathrm{j} \omega} \chi \ldots \ldots \ldots \ldots \ldots \ldots \ldots \ldots \ldots \ldots \ldots
\end{aligned}
$$

以上より, $\boldsymbol{A}-\phi-a$ 法では, 辺に割り当てられた未知変数の個 数を $N_{A}$, 節点に割り当てられた未知変数の個数を $N_{\phi}$, 導 波管の入出力ポートの個数（反射波複素振幅比の個数）を $N_{a}$ とすると, 未知変数の総数は, $N_{A}+N_{\phi}+N_{a}$ となる。

$\langle\mathbf{2} \cdot \mathbf{2}\rangle$ 熱伝導解析 被加熱体の時間的な加熱状況を 詳細に把握するため, 熱伝導解析では (31) 式に示す非定常 熱伝導方程式を使用する。

$$
\operatorname{div}(\lambda \operatorname{grad} T)+Q=\rho c \frac{\partial T}{\partial t}
$$

ここで，入は熱伝導率， $Q$ は単位時間に供給される単位体 積当たりの熱量 (発熱率), $\rho$ は密度, $c$ は比熱, $T$ は温度 を示す。節点要素の補間関数 $N_{i}$ を用いて, 節点 $i$ における (31) 式の弱形式を導くと，(32) 式のようになる。

$$
\begin{aligned}
G_{i}^{\text {heat }}= & \iiint_{V} \operatorname{grad} N_{i} \cdot \lambda \operatorname{grad} T \mathrm{~d} V \\
& +\iiint_{V} N_{i} \rho c \frac{\partial T}{\partial t} \mathrm{~d} V-\iiint_{V} N_{i} Q \mathrm{~d} V \\
& -\iint_{S} N_{i}(\lambda \operatorname{grad} T) \cdot \boldsymbol{n} \mathrm{d} S=0 \ldots \ldots \ldots
\end{aligned}
$$

(32) 式の時間微分項には，後退差分近似を適用し，完全陰 解法で解く。熱伝導解析を行う領域と空気部が接触してい る境界では, 固体壁から空気部 (流体側) へ対流によって, 熱が伝達される。そのため, (32) 式の右辺第四項目の境界 積分項は，(33) 式のように変形できる ${ }^{(10)}$ 。

$$
-\iint_{S} N_{i}(\lambda \operatorname{grad} T) \cdot \boldsymbol{n} \mathrm{d} S=\iint_{S} N_{i} h\left(T-T_{f}\right) \mathrm{d} S
$$

ここで, $h$ は熱伝達率, $T_{f}$ は空気部 (流体側) の温度である。

$\langle\mathbf{2} \cdot \mathbf{3}\rangle$ 連成解析の概略計算手順 共通の变数を媒介 として，異なる方程式を連成させる手法を弱連成法と呼ぶ。 これに対して, 異なる方程式を一括して, 同時に解く方法は 強連成法と呼ばれる ${ }^{(11)} 。$ 一般に, 弱連成法では, 開発済み の解析コードが利用可能である。一方，強連成法では，異 なる方程式を結合させる新たな定式化，それに適した行列 解法, 解析コードの大幅な修正が必要となるため, 本研究 では弱連成法を使用する。本節では，弱連成法に基づいた 電磁波解析と熱伝導解析の連成法について説明する。

電磁波・熱伝導連成解析のフローチャートを図 3 に示す。 まず, 初期時刻 $(t=0)$ における温度 $T_{0}$ を設定する $($ step 1$)$ 。 次に, 温度依存性の複素誘電率を考慮する領域における各 要素の積分点では, 設定した温度に相当する複素誘電率を計 算して (step 2)，周波数領域で電磁波解析を行う（step 3)。 複素誘電率と電磁波解析により得られた電界を用いて, 損 失性誘電体の各積分点における誘電損失 $P_{d}$ を (34) 式によ り計算し, (32) 式の発熱率 $Q$ に受け渡す（step 4）。

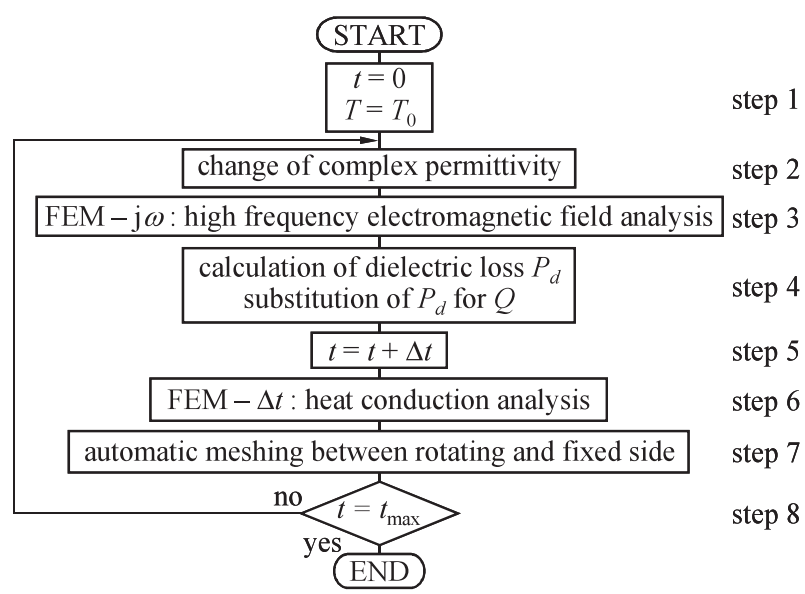

図 3 連成解析のフローチャート

Fig. 3. Flow chart of coupled analysis.

$$
P_{d}=\omega\left|\boldsymbol{E}_{e f f}\right|^{2} \varepsilon_{0} \varepsilon^{\prime} \tan \delta .
$$

ここで， $\varepsilon^{\prime}$ は複素比誘電率の実部， $\delta$ は複素比誘電率の実 部と虚部の偏角, $\boldsymbol{E}_{\text {eff }}$ は電界の実効值とする。なお, 温度 依存性複素誘電率と $\tan \delta$ の取り扱い方については, 次章 で述べる。続いて, step 4 で得られた $Q$ を用いて, 熱伝導 解析を行う (step 6)。次に, ターンテーブル等の回転運動 を考慮するため, 有限要素メッシュを修正する（step 7)。 メッシュの修正法については，次章で述べる。以上の手順 (step 2〜 step 7) を指定時刻 $t_{\max }$ まで, 繰り返し計算を行っ て連成解析を終了する (step 8)。

\section{3. 材料定数の温度依存性とメッシュ修正法}

$\langle\mathbf{3} \cdot \mathbf{1}\rangle$ 温度依存性複素誘電率誘電体に高周波電界 が加えられると, 誘電体内の誘電分子の振動が, 電界の振 動に追従できなくなる。この時の振動の遅れから誘電加熱 される。その場合, 比誘電率 $\varepsilon_{r}$ は (35) 式のように, 複素 数として表示することができる( ${ }^{(9)}$ 。

$$
\varepsilon_{r}=\varepsilon^{\prime}-\mathrm{j} \varepsilon^{\prime \prime}
$$

ここで，実部と虚部の偏角 $\delta$ は，図 4 のようになる。被加 熱体として使用する PVCの $\tan \delta$ は, 温度に対して, 指数 関数的に増加することが確認されている ${ }^{(12)}$ 。これより, 温 度 $T$ と $\tan \delta$ の特性曲線は, 指数関数を用いて (36) 式のよ うに近似することができる。

$$
\tan \delta=\beta e^{T / T_{v}}
$$

本研究で使用する硬質 PVCでは, $\beta=0.0004, T_{v}=100 \mathrm{~K}$ とする ${ }^{(12)}$ ここの特性曲線を図 5 に示す。なお, 本論文では, 複素比誘電率の実部は一定 $(=5.0)$ とし, 虚部のみを温度 依存性として取り扱う。

$\langle\mathbf{3} \cdot 2\rangle$ 有限要素メッシュの修正法 電子レンジのター ンテーブルのように, 解析領域内部に回転周期 $T_{r}$ で回転す る領域を包含した連成解析手法を説明する。まず，図 6(a) に示すように, 熱伝導解析領域が含まれている回転側と静 
止側の各領域を決定する。次に，図 6(b) のように，熱伝導 解析の時間刻み幅 $\Delta t$ に追従させて， $2 \pi \Delta t / T_{r} \mathrm{rad}$ だけ回転 領域の節点座標を移動させる。その結果，回転領域と静止 領域の境界面 $l$ では，双方の領域における節点の非適合が 生じる。そこで，図 6(c) に示すように，境界面 $l$ 上の回転 領域側の節点座標には修正を加えず，静止領域側の節点座 標を回転領域側の最も近距離の節点座標に修正し，要素を 再構成する ${ }^{(13)}$ 。このとき，境界面 $l$ を含む回転領域に属す る絶対節点番号，相対節点番号，要素番号には修正を加え ずに，静止領域側のメッシュデータのみを変更する。

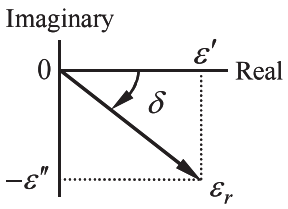

図 4 複素誘電率

Fig. 4. Complex permittivity.

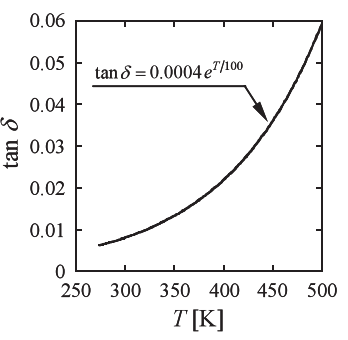

図 $5 T-\tan \delta$ 特性

Fig. 5. Characteristic of $T-\tan \delta$.

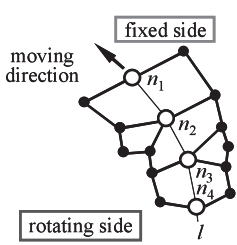

(a) Initial position

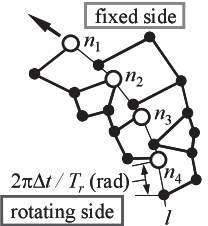

(b) Motion of rotating side

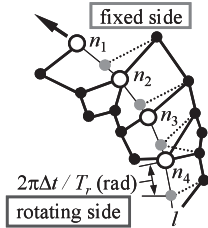

(c) Nodal re-connection in fixed side
図 6 回転運動を考慮するための有限要素 メッシュの修正法

Fig. 6. Automatic meshing with rotational motion.

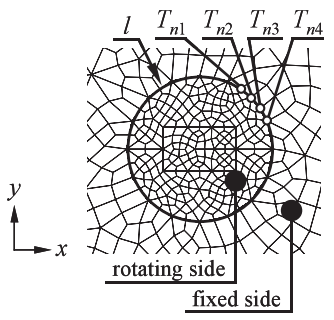

(a) Initial position

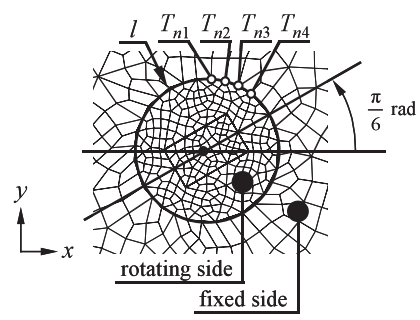

(b) After rotation
図 7 回転運動に伴う各節点における温度の移動 (機械角 $: \pi / 6 \mathrm{rad}$ )

Fig. 7. Displacement of nodal temperature in rotational motion (mechanical angle: $\pi / 6 \mathrm{rad}$ ).
上記の方法を使用すると，図７に示すように，メッシュ 回転後の温度データの保持が容易となる。なお，この方法 を使用するには，境界面 $l$ 上の節点を周方向に対して，ほぼ 等間隔で配置させ，三次元有限要素メッシュは，二次元有 限要素メッシュを積み上げて作成することが制約となる。

\section{4. 解 析 例}

〈4・1〉 解析モデルと解析条件 提案した電磁波・熱伝 導連成解析手法の有用性を検証するため, 図 8 に示すよう な共振器 (SHARP 製電子レンジ : RE-S120-B) を解析対象 とする。直径 $265 \mathrm{~mm}$, 厚さ $2 \mathrm{~mm}$ のターンテーブル (ホウ 珪酸ガラス) 上に直方体形状の PVC $\left(60 \times 160 \times 20 \mathrm{~mm}^{3}\right)$ を配置し，入力ポートより電界が $z$ 方向成分のみの $\mathrm{TE}_{10}$ モード（周波数 $f=2.45 \mathrm{GHz} ， 500 \mathrm{~W}$ ) の電磁波を $-x$ 方 向に対して入射する。入力ポート以外の共振器の外部境界 は完全導体とし $, \boldsymbol{A} \times \boldsymbol{n}=\mathbf{0}, \phi=0$ の境界条件を与え，入 力ポート上の $A, \phi$ は未知変数とする。

表 1 に，ホウ珪酸ガラスと PVCの各材料定数を示す。ホ ウ珪酸ガラス, PVC は損失性誘電体であるため, (34) 式を 用いて誘電損失を計算し，(32) 式の熱源 $Q$ として熱伝導解 析へ受け渡す。なお, 各積分計算には, ガウス積分の 2 点則 を使用している。表 2 に解析条件を示す。電磁波解析 (EM analysis）では ICCOCG 法，熱伝導解析（HC analysis）で

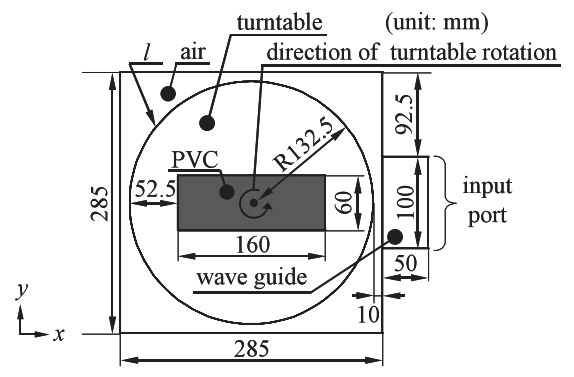

(a) $x-y$ cross section

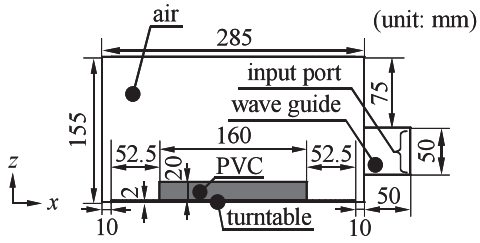

(b) $x-z$ cross section

図 8 解析モデル

Fig. 8. Analyzed model.

表 1 材料定数 $(T=293.15 \mathrm{~K})$

Table 1. Material constants $(T=293.15 \mathrm{~K})$.

\begin{tabular}{|c|c|c|c|}
\hline \multicolumn{2}{|l|}{ material } & $\begin{array}{c}\text { turntable } \\
\text { (pyrex) }\end{array}$ & PVC \\
\hline \multicolumn{2}{|c|}{ relative permeability } & 1 & 1 \\
\hline \multirow{2}{*}{ complex relative permittivity } & real part & 4.3 & 5.0 \\
\hline & imaginary part & -0.0200 & -0.0075 \\
\hline \multicolumn{2}{|c|}{ mass density: $\rho\left[\mathrm{kg} / \mathrm{m}^{3}\right]$} & 2230 & 1400 \\
\hline \multicolumn{2}{|c|}{ specific heat: $c[\mathrm{~J} / \mathrm{kg} \cdot \mathrm{K}]$} & 740 & 950 \\
\hline \multicolumn{2}{|c|}{ thermal conductivity: $\lambda[\mathrm{W} /(\mathrm{m} \cdot \mathrm{K})]$} & 1.10 & 0.16 \\
\hline
\end{tabular}




\section{表 2 解析条件}

Table 2. Analyzed conditions.

\begin{tabular}{|c|c|c|}
\hline \multicolumn{2}{|c|}{ rotation period of the turntable: $T_{r}[\mathrm{~s}]$} & 24 \\
\hline \multicolumn{2}{|c|}{ heat transfer coefficient: $h\left[\mathrm{~W} / \mathrm{m}^{2} \cdot \mathrm{K}\right]$} & 4 \\
\hline \multicolumn{2}{|c|}{ intial temperature of heat conductoin analysis: $T_{0}[\mathrm{~K}]$} & 293.15 \\
\hline \multicolumn{2}{|c|}{ air region temperature: $T_{f}[\mathrm{~K}]$} & 293.15 \\
\hline \multicolumn{2}{|c|}{ heated time: $t_{\max }[\mathrm{s}]$} & 96 \\
\hline \multirow{2}{*}{$\begin{array}{l}\text { convergence criterion } \\
\text { of ICCG method }\end{array}$} & complex type (EM analysis) & $10^{-6}$ \\
\hline & real type (HC analysis) & $10^{-6}$ \\
\hline
\end{tabular}

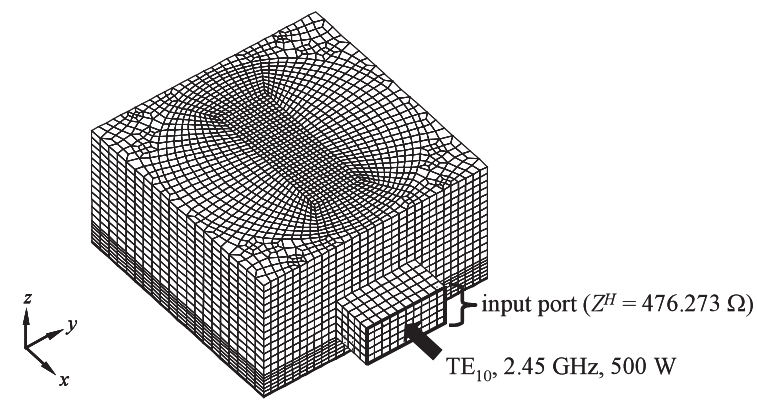

number of nodes: 38,027 number of edges: 110,976 number of elements: 35,110 number of unknowns: 132,358 $(\boldsymbol{A}-\boldsymbol{\phi}-a), 99,922(\boldsymbol{E}-a)$

(a) Mesh for electromagnetic field analysis (whole region)

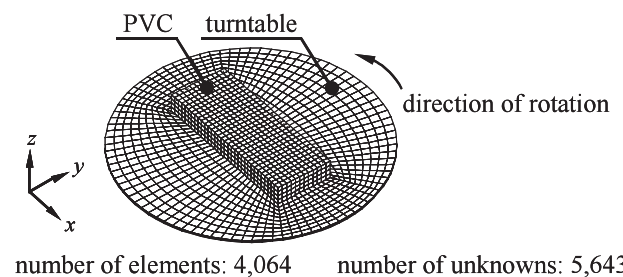

(b) Mesh for heat conduction analysis (PVC and turntable)

困 9 電磁波・熱伝導連成解析で使用する分割図

Fig. 9. Mesh for the EM-HC coupled analysis.

は ICCG 法を適用し, 残差ノルムが初期ノルムに対して， $10^{-6}$ 未満となれば反復計算を終了させる。

図 9 に連成解析で使用する分割図を示す。電磁波解析の 領域は共振器内部の全領域, 熱伝導解析の領域は被加熱体 である PVC とターンテーブルとし，空気部と接触してい る境界面には，(32) 式で示した熱伝達境界積分を考慮する。 電磁波解析，熱伝導解析とも，同様のメッシュを使用して 連成解析を行う。なお, 辺要素, 節点要素には, 双方とも アイソパラメトリック六面体一次要素を使用する。

〈4·2〉 ICCOCG 法の収束特性 本節では, 第 2 章で 定式化を行った $\boldsymbol{A}-\phi-a$ 法による定式化の優位性を検証する ため, 文献 (6) で示されている $\boldsymbol{E}$ 法に基づたた定式化 $(\boldsymbol{E}-a$ 法）を用いた場合の ICCOCG 法の収束特性と比較する。な お，解析条件として，T=293.15 K における各材料定数を 使用し, ターンテーブルは図 8 の位置で静止した状態を採 用する。ICCOCG 法の収束特性を図 10 に示す。複素対称 方程式の反復 $n$ 回目における残差ノルムの初期ノルムに対 する比 $\left(\left\|\boldsymbol{r}_{n}\right\| /\left\|\boldsymbol{r}_{0}\right\|\right)$ の減少過程より, 定式化に $\boldsymbol{A}-\phi-a$ 法を 使用した方が， $\boldsymbol{E}-\boldsymbol{a}$ 法よりも収束特性が良好であることを 確認できる。

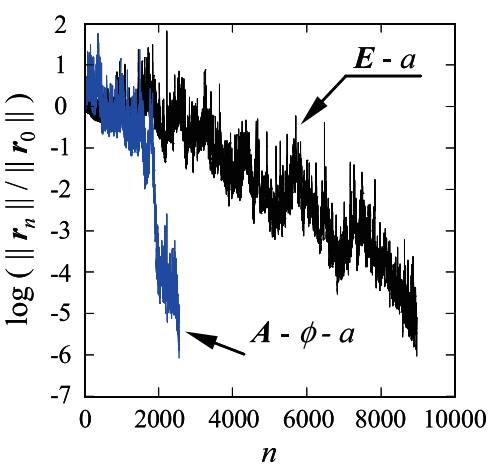

図 10 ICCOCG 法の収束特性

Fig. 10. Convergence characteristics of ICCOCG method.

\section{表 3 電磁波解析の各定式化における ICCOCG 法の計算時間}

Table 3. Computation time of complex type ICCOCG method for each formulation in electromagnetic wave analysis.

\begin{tabular}{c|c|c|c}
\hline formulation & D. O. F. & iteration number & CPU time \\
\hline $\boldsymbol{E}-a$ & $99,922(1.00)$ & $8,971(1.00)$ & $628.01(1.00)$ \\
\hline $\boldsymbol{A}-\phi-a$ & $132,358(1.32)$ & $2,543(0.28)$ & $459.57(0.73)$ \\
\hline
\end{tabular}

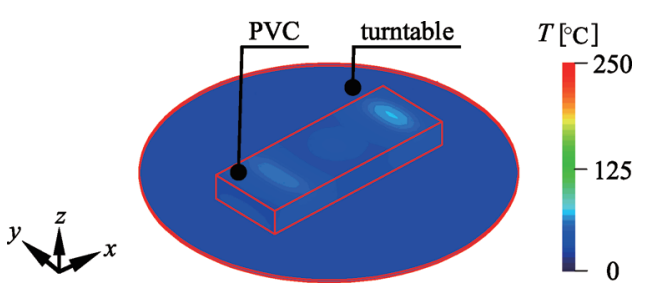

(a) Without turntable motion ( $\Delta t=1.0 \mathrm{~s}, 96^{\text {th }}$ time step)

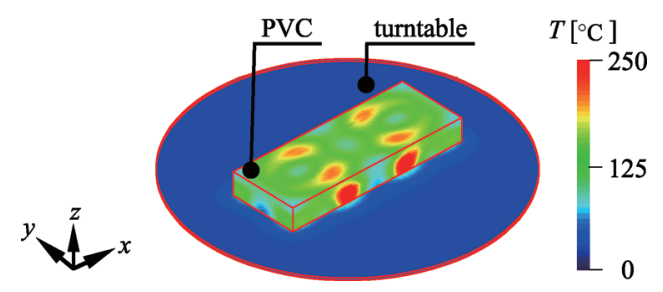

(b) With turntable motion $\left(\Delta t=0.0666 \mathrm{~s}, 1440^{\text {th }}\right.$ time step)

図 11 温度分布 $\left(t=t_{\max }\right)$

Fig. 11. Temperature distributions $\left(t=t_{\max }\right)$.

各定式化における ICCOCG 法の計算時間を表 3 に示す。 高周波領域の解析では, 空気領域に変位電流を考慮するた め, $\boldsymbol{A}-\phi-a$ 法の未知変数の個数 (D. O. F.) が, $\phi$ の未知変数 の個数だけ, $\boldsymbol{E}-a$ 法よりも多くなる。そのため, 同様のモ デルにおいて, ICCOCG 法の収束特性が向上しても, それ に対応する速度向上効果は得られていない。しかし, A- $\phi-a$ 法を採用することで, $\boldsymbol{E}-\boldsymbol{a}$ 法の計算時間を約 $1 / 4$ 削減でき ることが確認できる。以上より, 計算時間削減の観点から, 電磁波解析には, $\boldsymbol{A}-\phi-a$ 法による定式化を使用する。

〈4・3〉 誘電加熱特性連成解析より得られたPVCの 加熱状況を図 11 に示す。ターンテーブルの回転運動を考慮 しないケースでは, 過熱箇所が局在化しているが, 温度上昇 


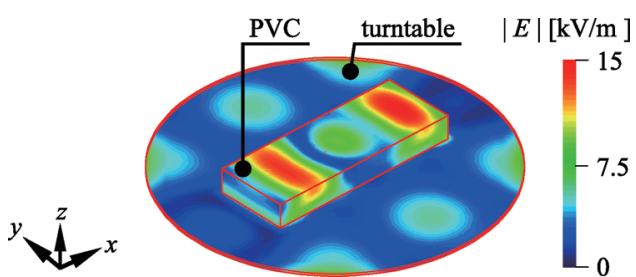

(a) Initial position $\left(\left|S_{11}\right|=0.961\right)$

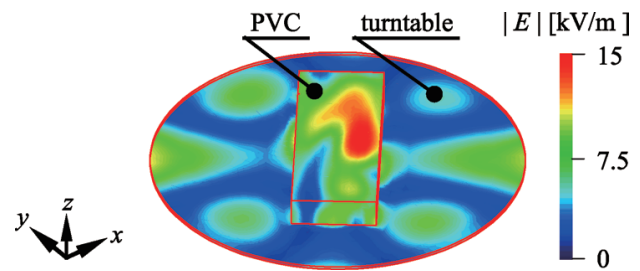

(b) Mechanical angle: $\pi / 4 \mathrm{rad}\left(\left|S_{11}\right|=0.951, \Delta t=0.0666 \mathrm{~s}, 45^{\text {th }}\right.$ time step)

図 12 電界強度分布

Fig. 12. Distributions of electric field intensity.

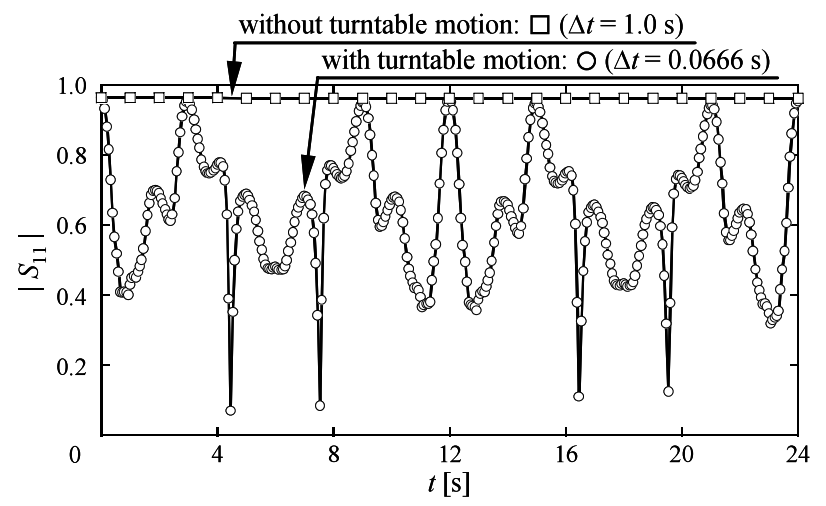

図 13 反射係数 $\left|S_{11}\right|$ の時間変化

Fig. 13. Time variation of reflection coefficient $\left|S_{11}\right|$.

はあまり確認されない。一方，ターンテーブルの回転運動 を考慮した結果では, 温度上昇がPVCの広い範囲で確認で きる。これは, 図 12 に示すように, ターンテーブルの各位 置によって, 電界強度分布が大幅に異なるため, 誘電損失 により生じる熱源の場所も異なるためである。ターンテー ブルの一周期分の反射係数 $\left|S_{11}\right|$ の時間変化を図 13 に示す。 ターンテーブルが静止したケースでは， $\left|S_{11}\right|$ はほとんど変 化せずに一定であるが，ターンテーブルの回転を考慮する と，各機械角によって，|S $S_{11} \mid$ が大幅に変化していることが わかる。なお，ターンテーブルが図 11(a) の位置では, $\left|S_{11}\right|$ が大きく, 損失性誘電体のエネルギー吸収効率が悪いため, ほとんど加熱されていない。しかし，図 13 の $4.4 \mathrm{~s}$ 付近に おける $\left|S_{11}\right|$ が極小の回転位置を採用すれば，図 11(a)の場 合よりも，さらに加熱されることが予想される。

$\langle\mathbf{4} \cdot \mathbf{4}\rangle$ 時間刻み幅に対する温度上昇特性時間刻み 幅 $\Delta t$ を数パターン変化させた場合の温度上昇特性を図 14 に示す。なお, その評価点は, 温度上昇が顕著である要素番 号 108 の要素重心とする。ターンテーブルの回転による影 響のため，階段状に温度が上昇しており， $\Delta t$ を $0.3333 \mathrm{~s}$ 以 下に設定した温度上昇特性は，それぞれがほぼ一致してい

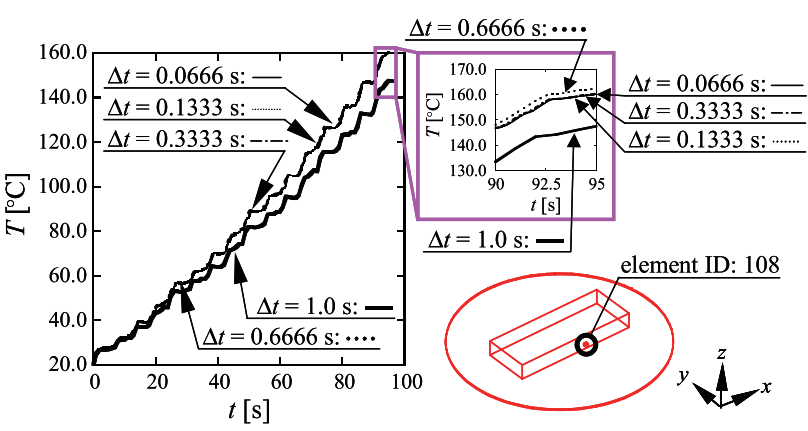

図 14 時間刻み幅が温度上昇に与える影響

Fig. 14. Effect of time step size on temperature rise.

表 4 時間刻み幅に依存した温度の相対誤差

Table 4. Relative error of temperature depending on time step size.

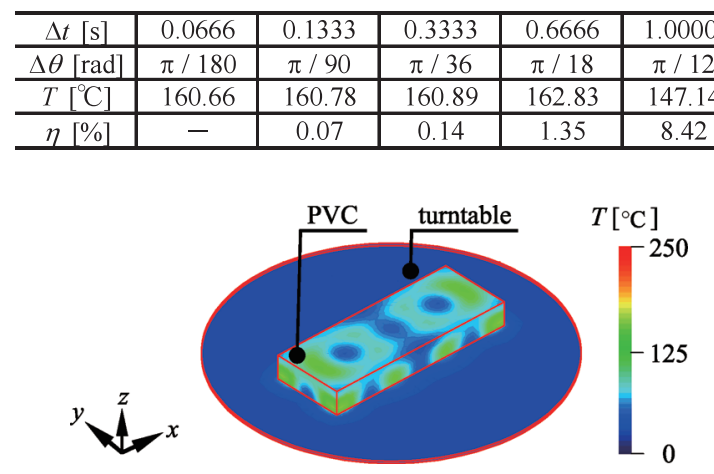

(a) $\Delta t=4.0 \mathrm{~s}, \Delta \theta=\pi / 3$

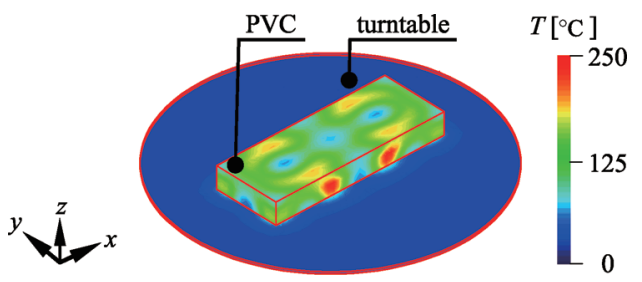

(b) $\Delta t=2.0 \mathrm{~s}, \Delta \theta=\pi / 6$

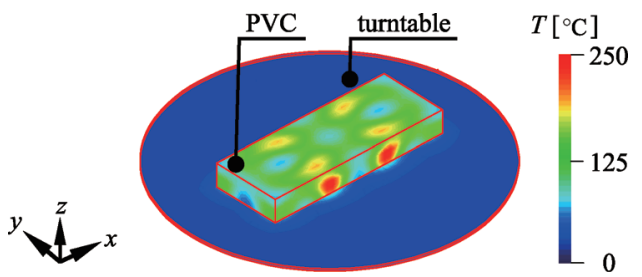

(c) $\Delta t=1.0 \mathrm{~s}, \Delta \theta=\pi / 12$

図 15 時間刻み幅が温度分布に与える影響

Fig. 15. Effect of time step size on temperature distribution.

ることがわかる。表 4 に, 各時間刻み幅に対する要素番号 108 の最終温度の相対誤差を示す。ここで， $\Delta t$ を $0.0666 \mathrm{~s}$ とした場合の最終温度を真值とする。 $\Delta t$ を $0.3333 \mathrm{~s}$ 以下に 設定すれば，相対誤差が $0.2 \%$ 以下の解析が可能である。

時間刻み幅の選定による温度分布の差異を図 15 に示す。 時間刻み幅 1 ステップ当たりの回転角 $(\Delta \theta)$ が小さいほど, 図 11(b) の結果に近づいている。また，回転角が大きいほ 
表 5 電磁波・熱伝導連成解析の計算時間

Table 5. CPU time of EM-HC coupled analysis.

\begin{tabular}{c|c|r|r}
\hline$\Delta t[\mathrm{~s}]$ & $\Delta \theta[\mathrm{rad}]$ & \multicolumn{1}{|c|}{ N. O. T. S. } & \multicolumn{1}{|c}{ CPU time $[\mathrm{h}]$} \\
\hline 0.0666 & $\pi / 180$ & $1440(1.0000)$ & $135.7(1.0000)$ \\
\hline 0.1333 & $\pi / 90$ & $720(0.5000)$ & $68.1(0.5018)$ \\
\hline 0.3333 & $\pi / 36$ & $360(0.2500)$ & $27.3(0.2012)$ \\
\hline 0.6666 & $\pi / 18$ & $180(0.1250)$ & $13.6(0.1002)$ \\
\hline 1.0000 & $\pi / 12$ & $96(0.0667)$ & $9.1(0.0671)$ \\
\hline
\end{tabular}

CPU: Intel Pentium 4 3.72 GHz/ 3.0 GB, COMPILER: Intel Visual Fortran Ver. 9

ど，最終的に得られる温度が低いことを確認できる。この 原因は，回転角が大きすぎると，共振器内の電磁界モードの 時間的な変化を，正しく評価することができないためであ る。なお， $\Delta t$ に $0.6666 \mathrm{~s}$ 以下の值を採用した温度分布は， 図 11(b) とほぼ同様であったため，ここでは省略する。

$\langle\mathbf{4} \cdot \mathbf{5}\rangle$ 連成解析の計算時間 加熱時間 $t_{\max }$ を一定と して，時間ステップ数，時間刻み幅を変化させた電磁波・ 熱伝導連成解析の計算時間を表 5 に示す。これより，熱伝 導方程式の時間ステップ数（N. O. T. S.）の増加に概ね比 例して，計算時間が増えている。これは，電磁波解析で使 用している ICCOCG 法の計算時間が, 総計算時間の 9 割 以上を占めていることが原因である。

\section{5. まとめ}

本論文では，有限要素法による被加熱体の回転運動と温 度依存性の複素誘電率を考慮した電磁波・熱伝導連成解析 手法を提案した。以下に，得られた知見を要約する。

（1）電磁波解析の弱定式化において，電界 $\boldsymbol{E}$ を未知変 数とした方程式に, 散乱行列を考慮した定式化 $(\boldsymbol{E}-a$ 法 $)$ を 磁気ベクトルポテンシャル $\boldsymbol{A}$ と電気スカラポテンシャル $\phi$ を用いた $\boldsymbol{A}-\phi-a$ 法へ拡張した。その結果，未知変数の数が $\boldsymbol{E}-a$ 法に対して, 1.3 倍程度の増加があるものの, ICCOCG 法の収束特性を向上させることが可能となり, $\boldsymbol{E}-\boldsymbol{a}$ 法の計 算時間を約 $1 / 4$ 低減できることが明らかとなった。

（2）ターンテーブルの回転運動を考慮すると, 共振器 内に種々の電磁界モードが生じるため, 被加熱体の温度分 布が一様化されることが確認された。また，被加熱体の温 度は階段状に上昇している特性が明らかとなった。

（3）提案した電磁波・熱伝導連成解析手法では，熱伝 導方程式の時間刻み幅に追従させて, 連成解析を行ってい る。そこで，時間刻み幅の大きさが，温度上昇特性に与え る影響を検討した。その結果，本論文で使用する直方体形 状のような被加熱体では，時間刻み幅 1 ステップ当たりの 回転角を $\pi / 36 \mathrm{rad}$ 以下に設定すれば，回転角が $\pi / 180 \mathrm{rad}$ の場合と, ほぼ同程度の精度で解析が可能であることが明 らかとなった。

（4）電磁波解析では, 複素対称方程式の解法として使 用する ICCOCG 法の収束特性が好ましくない。それゆえ, 提案した連成解析手法に要する計算時間の 9 割以上が, ICCOCG 法による連立一次方程式の求解に依存しているため, 熱伝導解析の時間ステップ数にほほ比例して計算時間が増
加する傾向であった。

今後は, 実験結果との比較, ステラファンの運動を厳密 に考慮した解析手法の確立, 並びに, 連成解析のさらなる 高速化を図るため, 並列化処理等の導入を行い, 高効率り サイクル誘電加熱炉の実機設計に適用する予定である。

本論文は, 平成 18 年度電気学会静止器・回転機合同研究 会発表資料 SA-06-71, RM-06-73 の内容に, 加筆, 修正を 加えたものである。

(平成 18 年 10 月 31 日受付，平成 19 年 3 月 8 日再受付)

\section{文献}

(1) K.S. Yee: "Numerical solution of initial boundary value problems involving Maxwell's equations in isotropic media", IEEE Trans. Antennas Propagat., Vol.14, No.4, pp.202-207 (1966)

(2) F. Torres and B. Jecko: "Complete FDTD analysis of microwave heating process in frequency-dependent and temperature-dependent media", IEEE Trans. Microwave Theory Tech., Vol.45, No.1, pp.108-117 (1997)

(3) P. Ratanadecho, K. Aoki, and M. Akahori: "A numerical and experimental investigation of the modeling of microwave heating for liquid layers using a rectangular wave guide (effects of natural convection and dielectric properties)", J. Appl. Math. Model., Vol.26, pp.449-472 (2002)

(4) S. Watanabe, K. Saito, and O. Hashimoto: "Three dimensional analysis of temperature distribution of one-layer wave absorber considering air convection", IEICE Trans. C, Vol.J88, No.1, pp.76-78 (2005-1) (in Japanese) 渡邊慎也・斉藤耕太・橋本 修:「三次元領域における対流を考慮し た一層型電波吸収体の温度解析」, 信学論 C, J88, 1, pp.76-78 (2005-1)

(5) A. Sekkak, L. Pichon, and A. Razek: "3-D FEM magneto-thermal analysis in microwave ovens", IEEE Trans. Magn., Vol.30, No.5, pp.3347-3350 (1994)

(6) Y. Nomura, M. Tsuji, and H. Shigesawa: "Vector finite-element method based on use of hybrid edge elements and its application to threedimensional electromagnetic waveguide-discontinuity", IEICE Trans. C-I, Vol.J78, No.1, pp.36-44 (1995-1) (in Japanese)

野村美徳・辻 幹男・繁沢 宏：「辺要素混合使用によるベクトル有 限要素法とその 3 次元電磁導波路不連続問題への応用」, 信学論 C-I, J78, 1, pp.36-44 (1995-1)

( 7 ) K. Fujiwara, T. Nakata, and H. Ohashi: "Improvement of convergence characteristic of ICCG method for the $\boldsymbol{A}-\phi$ method using edge elements", IEEE Trans. Magn., Vol.32, No.3, pp.804-807 (1996)

(8) R. Dyczij-Edlinger and O. Biro: "A joint vector and scalar potential formulation for driven high frequency problems using hybrid edge and nodal finite elements", IEEE Trans. Microwave Theory Tech., Vol.44, No.1, pp.15-23 (1996)

（9）岡田文明：マイクロ波工学, 山海堂 (2004)

（10）矢川元基：流れと熱伝導の有限要素法入門, 培風館 (1983)

(11) Q. Zhang and T. Hisada: "Investigation of the coupling methods for FSI analysis by FEM", JSME Trans. A, Vol.67, No.662, pp.1555-1562 (2001) (in Japanese)

張群 · 久田俊明:「流体 ·構造連成有限要素解析における連成 手法に関する検討」, 機械学会論 A, 67, 662, pp.1555-1562 (2001)

(12) K. Murata, A. Hanawa, and R. Nozaki: "Broadband complex permittivity measurement technique of materials with thin configuration at microwave frequencies", J. Appl. Phys., Vol.98, No.84107, pp.1-8 (2005)

(13)「回転機の電磁界高精度数值シミュレーション技術」, 電気学会技術 報告, No.565 (1995)

(14) 卯本重郎：電磁気学, 昭晃堂 (1975)

\section{付 録}

\section{1. 電流連続式の弱形式における境界積分項の導出}

電流連続式の弱形式 (4) 式における境界積分項の導出を 試みる。節点要素の補間関数 $N_{j}$ を用いると, (2) 式の残差 方程式は，(付 1) 式のようになる。 


$$
\begin{aligned}
G_{j}^{\text {node }}= & \iiint_{V} \operatorname{grad} N_{j} \cdot \varepsilon(\mathrm{j} \omega \boldsymbol{A}+\operatorname{grad} \phi) \mathrm{d} V \\
& -\iint_{S} \varepsilon N_{j}(\mathrm{j} \omega \boldsymbol{A}+\operatorname{grad} \phi) \cdot \boldsymbol{n} \mathrm{d} S=0
\end{aligned}
$$

なお，係数マトリクスが対称となるように，（付 1）式を時 間積分している。ここで，アンペアの法則の微分形表現式

$$
\boldsymbol{E}=\frac{1}{\mathrm{j} \omega \varepsilon} \operatorname{rot} \boldsymbol{H}
$$

を（付 1) 式における右辺第二項の境界積分項へ代入すると，

$$
\begin{aligned}
- & \iint_{S} \varepsilon N_{j}(\mathrm{j} \omega \boldsymbol{A}+\operatorname{grad} \phi) \cdot \boldsymbol{n} \mathrm{d} S \\
= & \iint_{S} \varepsilon N_{j} \boldsymbol{E} \cdot \boldsymbol{n} \mathrm{d} S \\
= & \frac{1}{\mathrm{j} \omega} \iint_{S} N_{j} \operatorname{rot} \boldsymbol{H} \cdot \boldsymbol{n} \mathrm{d} S \cdots
\end{aligned}
$$

となる。次に, ベクトル公式 ${ }^{(14)}$

$$
\operatorname{rot}(V \boldsymbol{x})=(\operatorname{grad} V) \times \boldsymbol{x}+V \operatorname{rot} \boldsymbol{x}
$$

を(付 3) 式に適用する。ここで，(付 4) 式における $V$ はス カラ関数, $\boldsymbol{x}$ はべクトル関数とする。(付 4) 式を適用する と, (付 3) 式は (付 5) 式のように展開できる。

$$
\begin{aligned}
\frac{1}{\mathrm{j} \omega} & \iint_{S} N_{j} \operatorname{rot} \boldsymbol{H} \cdot \boldsymbol{n} \mathrm{d} S \\
= & -\frac{1}{\mathrm{j} \omega} \iint_{S}\left\{\left(\operatorname{grad} N_{j}\right) \times \boldsymbol{H}\right\} \cdot \boldsymbol{n} \mathrm{d} S \\
& +\frac{1}{\mathrm{j} \omega} \iint_{S} \operatorname{rot}\left(N_{j} \boldsymbol{H}\right) \cdot \boldsymbol{n} \mathrm{d} S \cdots \cdots
\end{aligned}
$$

(付 5) 式における右辺第二項の境界積分は, ストークスの 定理 ${ }^{(14)}$ を適用すると，(付 6) 式のように線積分へ変形する ことができる。

$$
\frac{1}{\mathrm{j} \omega} \iint_{S} \operatorname{rot}\left(N_{j} \boldsymbol{H}\right) \cdot \boldsymbol{n} \mathrm{d} S=\frac{1}{\mathrm{j} \omega} \oint_{C} N_{j} \boldsymbol{H} \cdot \mathrm{d} \boldsymbol{l}
$$

ここで, $C$ は境界面 $S$ の周回上における閉曲線, $\mathrm{d} \boldsymbol{l}$ は $C$ 上 の線要素ベクトルとする。完全導体表面では, $\boldsymbol{A} \times \boldsymbol{n}=\mathbf{0}$, $\phi=0$ の境界条件を課すため, (付 6) 式は 0 となる。また, 磁気壁上では, $\boldsymbol{H} \cdot \mathrm{d} \boldsymbol{l}=0$ となるため, 完全導体表面と同 様に，(付 6) 式は 0 となる。以上より，(付 3)，(付 5), (付 6) 式を用いると，(付 1) 式は，(付 7) 式のようになる。

$$
\begin{aligned}
G_{j}^{\text {node }}= & \iiint_{V} \operatorname{grad} N_{j} \cdot \varepsilon(\mathrm{j} \omega \boldsymbol{A}+\operatorname{grad} \phi) \mathrm{d} V \\
& -\frac{1}{\mathrm{j} \omega} \iint_{S} \operatorname{grad} N_{j} \cdot(\boldsymbol{H} \times \boldsymbol{n}) \mathrm{d} S=0
\end{aligned}
$$

岡 本吉史 (正員) 1978 年 3 月 31 日生。 2000 年関西大学

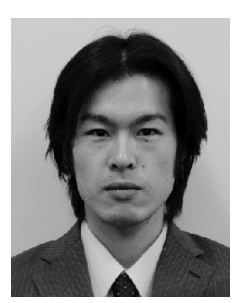
工学部電気工学科卒業。2002 年同大学大学院工学 研究科博士前期課程修了。2005 年 3 月岡山大学 大学院自然科学研究科博士後期課程修了。同年 4 月理化学研究所入所, 現在に至る。博士 (工学)。 主として, 低周波・高周波電磁界解析手法, なら びに連成解析の高度化に関する研究に従事。

姫野 龍太郎 (非会員) 1955 年 1 月 23 日生。1 1977 年京都大学

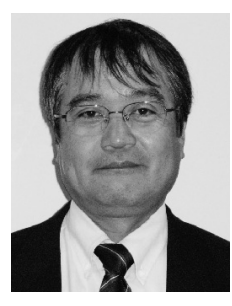
電気系学科卒業, 1979 年同大学院修士修了。1979 年日産自動車入社。1 1997 年から理化学研究所。現 在情報基盤センター長, 兼, 生体力学シミュレー ション特別研究ユニットリーダー, 次世代スーパー コンピュータ開発実施本部開発グループ・グルー プディレクタ。東京大学大学院・埼玉大学大学院 客員教授。主として, 生体に関連した血流等のシ ミュレーションの研究に従事。工学博士。

丑田公 規 (非会員) 1958 年 8 月 8 日生。1982 年京都大学

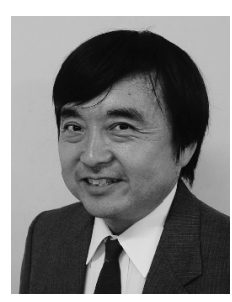
理学部化学科卒業, 1987 年同大学院博士課程修 了。同年京都工芸繊維大学工芸学部教務員, 1989 年同助手を経て, 1990 年より理化学研究所に勤 務。現在，環境ソフトマテリアル研究ユニット． ユニットリーダー。埼玉大学理工学研究科客員助 教授を兼任。主として，生体系や高分子などのソ フトマター (複雑系) に関する物性物理学の環境 分野への応用に関する研究に従事。理学博士。

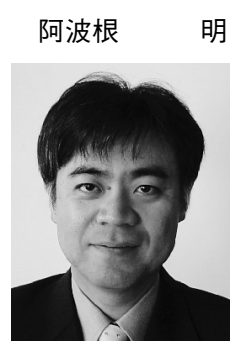

明（正員） 1964 年 4 月 15 日生。1987 年岡山大学 工学部電気工学科卒業。1989 年同大学大学院自 然科学研究科修士課程修了。同年 4 月松下電器産 業（株）入社。2002 年よりサイエンスソリュー ションズ (株) に勤務。現在，リサーチグループ ／西日本地区マネージャー。主として，低周波・ 高周波電磁界解析手法に関する研究に従事。電子 情報通信学会, IEEE 会員。

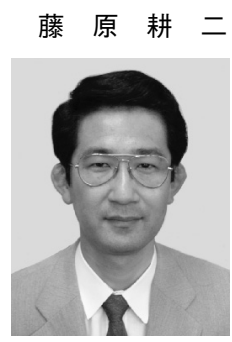

（正員） 1960 年 1 月 26 日生。1984 年 3 月岡山 大学大学院工学研究科電気工学専攻修士課程修了。 同年 4 月同大学大学院研究生。1985 年 4 月三井 造船（株）入社。1986 年 7 月岡山大学工学部助 手，1994 年 7 月同助教授， 2006 年 10 月同志社 大学工学部教授，現在に至る。博士 (工学)。主 として, 有限要素法による非線形および渦電流を 考慮した三次元磁界解析法, ならびに磁性材料の 標準磁気特性測定法に関する研究に従事。 